\begin{tabular}{|l|l|} 
Academic & $\begin{array}{l}\text { Institut Agama Islam Negeri (IAIN) Curup, Indonesia } \\
\text { Journal of } \\
\text { Islamic Studies }\end{array}$ \\
& ISS 2580-3174, (p); 2580-3190 (e) \\
& volume 6, number 2, 2021 | page: 181-206 \\
DOI: http://doi.org/10.29240/ajis.v6i2.3395
\end{tabular}

\title{
Religious Fundamentalism: Threats on Religious Life in West Sumatera-Indonesia
}

\author{
Novi Hendri, Ridha Ahida, Hardi Putra Wirman \\ Insitut Agama Islam Negeri (IAIN) Bukittinggi, Indoneisa \\ novihendri.1971@gmail.com
}

\begin{abstract}
This study aims to describe religious fundamentalism problems. Radicalism movement is caused by textual religious understanding and social as well political condition that are not conducive to the religious fundamentalism group. The finding of this research indicated that religious fundamentalism has transformed into radical and terrorism movement. The transformation of religious understanding from fundamentalism, radicalism, to terrorism is triggered by the dissatisfaction of radical group on the government, in terms of economic and political condition as well law enforcement activities. This research also indicated that religious radicalism group spreads the ideology by using mosque as the basis of their movement as well as educational institution. Mosque is also considered as power relation by religious radicalism group. This research was conducted through interviews and Focus Group Discussions with organizations and religious leaders categorized as Religious Fundamentalism.
\end{abstract}

Keywords: Religious fundamentalism, religious life, West Sumatera-Indonesia

\section{Introduction}

In the history of religion, it is often described that wars are used in spreading religion as well as upholding religion, for example, the crusade war between Moslem and Christian in the middle-ages. A lot of intrigues were shown by religious group in conquering their enemies. ${ }^{1}$

The rotation of power in the modern era has its own place. When violence becomes a way of life for an individual, a community or a state, the political economic and cultural process of the community had changed. Politic as the source of power is penetrated by negative

1Heonik Kwon and Seong Nae Kim, "Religions in Cold War Korea and Peacemaking: Guest Editors' Introduction," Journal of Korean Religions 9, no. 1 (2018): 5-10. 
influence and fear. There is a concern on the future, that violence can agitate political dialog and consumed its values. ${ }^{2}$

The phenomena of the growth of religious radicalism group by using recruiting system in order to form an Islamic state also spread into Indonesia especially to the Sumatera Island. ${ }^{3}$ Islamic radicalism group in Sumatera has been influenced by ideology of movement proposed by religious fundamentalism group like FPI, MMI, FUI, HTI, Tarbiyah Manhaj and others. It can be seen from a number of Islamic society groups in Sumatera that already joined that movement in the name of religion. As an illustration, when Ahok's religion blasphemy case emerged, thousands of people from Sumatera visited Jakarta in order to show that they were against Ahok. ${ }^{4}$ In the name of religion, ideology and religious symbol, people are willing to do whatever it takes to show their support.

Fundamentalism, radicalism, and terrorism movement is a serious threat to the existence of the state and religious community in Sumatera. Fundamentalism, radicalism, and terrorism are no longer related to aqidah matters; it is already derailed to the area of politics of power. Radicalism and terrorism action in the name of religion has become political authority to the radicalism group. ${ }^{5}$

Religious fundamentalist matters in west Sumatera have been put in the spotlight of Indonesian government. Fundamentalist changed into radicalism and then transformed into terrorism. Violence cases on behalf of religion have attracted peoples' attention in Sumatera. The attacking of police head-quarters in Solok, the restriction of Siloam hospital development in Padang, the arrest of terrorist who planned to do bombing attack in Payakumbuh, the attack of regional police chief of Riau, and the arrest of terrorist connected to Solo terrorism network in Medan

\footnotetext{
${ }^{2}$ Beverley Milton-Edwards, Islam and Violence in the Modern Era, (New York: Palgrave Macmillan, 2006), 19.

3Marcus Mietzner and Burhanuddin Muhtadi, "Explaining the 2016 Islamist Mobilisation in Indonesia: Religious Intolerance, Militant Groups and the Politics of Accommodation," Asian Studies Review 42, no. 3 (2018): 479-97.

${ }^{4}$ Mulkan Habibi, "Framing Kompas. Com Dan Republika. Co. Id Atas Pernyataan Ahok Tentang Dibohongi Al-Maidah 51," KAIS Kajian Ilmu Sosial 30, no. 1 (2021): 67-84.

${ }^{5}$ Herdi Sahrasad and Al Chaidar, "Radicalism, Fundamentalism and Terrorism in Indonesia: A Political Reflection," Journal of Asia Pacific Studies 5, no. 2 (2019).
} 
North Sumatera, are some of the example of violence cases related to the religion matters in Sumatera. ${ }^{6}$

Violence cases that happened in Sumatera is mostly caused by religion matters. It seems that religion is used for the advantages of certain groups. The spirit of religiosity is intentionally sparkled. passion for fighting in the name of religion, discrimination against Ulama until the spirit of jihad emerged in Sumatera as a form of resistance on the authority.

In addition, the Special Detachment 88 in West Sumatra arrested several religious figures, such as in Bukittinggi, 50 Kota, Payakumbuh, and Padang Panjang. This also happenned in several cities and regencies in North Sumatera and Riau Province. They were arrested on charges of having links with fundamentalist groups and planning various actions to threaten public peace and security.

Based on the problems mention above, the writer assumed that there is a problem on the appearance of religious fundamentalism in Sumatera as well as threads to the religious lives in Indonesia.

\section{The Root of Religious fundamentalism Groups}

\section{Textual understanding of religion}

Al-Quran, as a sacred text, describes roles on all dimensions of human lives. It describes how to govern a country which is supposed to be used as the theological foundation of politics.

Concepts as well as religious fundamentalism characteristics in Islam are reflected in several verses of Al-Quran and it is used as the basic foundation of the emergence of Islamic fundamentalism. ${ }^{8}$

"This day have I perfected your religion for your and completed my favor unto you, and have chosen for you as religion al-Islam", "we have

${ }^{6} \mathrm{C}$. Mahfud et al., "Religious Radicalism, Global Terrorism and Islamic Challenges in Contemporary Indonesia," Jurnal Sosial Humaniora 11, no. 1 (2018): 8-18.

${ }^{7}$ Peter Mandaville, Islam and Politics (Routledge, 2020).

${ }^{8}$ Deni Irawan and Zarul Arifin, "The Relationship Between Islamic Fundamentalism and Radicalism With Social Conflict," Al-Tahrir 21, no. 1 (2021): 35-53. 
neglected nothing in the book (of our decrees)", "and we reveal the Scripture unto thee as an exposition of all things", ${ }^{10}$ "and it becomes not a believing man or a believing woman, when Allah and his messenger have decided an affair (for them), that they should (after that) claim any say in their affair; and whose I rebellious to Allah and His messenger, he verily goeth astray in error manifest".."

The four verses mentioned above are understood as the verses that shows Al-Quran as a complete guidance (all problem related to human lives are discussed), and for Moslem, it is compulsory to take action to follow whatever stated in the verses. The concept in the verses of the AlQuran is later developed as the concepts of human lives. In the ideological concepts it is compulsory for Moslem to entirely believe in whatever stated in the Al-Quran. It refers to the verses: "o ye who believe! Come, all of you, into submission (unto Him); and follow not the footsteps of the devil. Lo! He is an open enemy for you". ${ }^{12}$

The verses above declared that it is obligatory for Moslem to totally follow Rabbany Manhaj, to use it as the guidance for privet life, social life as well as guidance to life in a state. ${ }^{13}$ Fundamentalists believe that all the activities to achieve their goals are based on the verses in the Al-Quran. "When the sacred months have passed, slay the idolaters wherever ye find them, and take them (captive), and besiege them, and prepare for them each ambush. But if they repent and establish worship and pay the poor-due, then leave their way free. Lo! Allah is forgiving, merciful." ${ }^{14}$

There are many other verses in the Al-Quran which are used as the guideline in making decision which is related to law and politics: the sovereign of law is on the hand of God, social concepts: Puritanism and social justice as well as religion theology concept : exclusivism. All those verses are literary understood by the fundamentalist without much regard of the historical and hermeutical aspects of the verses.

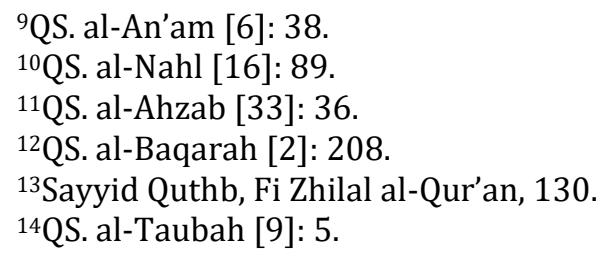


The basic ideas framed in methodological framework which contains the principal of: oppositionalism, resistance on hermeneutics, resistance on pluralism and relativism, as well as the resistance on the development of religion historically and sociologically are formed on the basis of literal understanding of the verses in the Al-Quran.

In the concept and characteristics of Islamic religion fundamentalist, Islamic fundamentalist attitude is derived from the verses of Al-Quran. Unfortunately, it only captures the literal meaning of each verses without relating it to other verses which discuss the same topics holistically and comprehensively. It also does not consider the historical point of view of those verses and then uses them as references.

\section{Anti-Western Modernism}

The second emergence of religious fundamentalism is antimodernity. In the point of view of fundamentalist groups, modernity is western civilization that is destructive to the Muslims. The western modernism is a culture that tries to ruin Islam in terms of culture and civilization. It also tries to rationalize the religion. Meanwhile, in the point view of religious fundamentalists, the rationality of modernity contrast to Islam culture since the religion and the religious understanding cannot be rationalized.

Furthermore, in the point view of fundamentalist groups, western modernity must be avoided by Muslims because it is one of the reasons of declining the Islam civilization. ${ }^{15}$

It is undeniable that religious radicalism will be directed to the Islam radicalism movement. Muslims are among the most vulnerable to the temptations of radicalism because their civilization still left behind. Moreover, it can encourage people to take shortcuts in achieving goals, but in the long-term, it is also leading to suffer, regret and failure. The Islam revival, especially in Asian countries, is manifested by the

${ }^{15}$ Ahmad Norma Permata, Agama Dan Terorisme (Surakarta: Muhamadiyah University Press, 2006), 187. 
acceptance of globalization and technology modernization, resulting in a 'clash of civilization' between Islam and Western. ${ }^{16}$

The West, which has lost its 'enemy' since the end of the Cold War, has started to consider Islam power as threat. The effects of globalization that are experienced by almost all people in the world allow this collision occurs. The Islam position as one of civilizations has the most possible potential for resistance to Western globalization.

Islam fundamentalism is generally identified as Islam political movements, even though it is only one component of a wider Islam revival which includes ideas, practices, rhetoric, and the return of Islam understanding (to its sources, Al-Qur'an and Al-Sunnah) that carried out by Muslims. Based on these ideas for the sake of returning of the Islam understanding or commonly called as the refinement of Islam understanding in the midst of a wave of globalization and technology modernization that raises the thoughts of radicalism. ${ }^{17}$

Through Western arrogance and global intolerance of Islam are always in conflict, the radical movements will develop in Islam countries. Supporters of the religious radicalism are unable to offer peace and prosperity in order to overcome the challenges of the democracy wave in the globalization. Shortness of breath due to various historical problems makes some Muslims in a tragic but helpless position. Therefore, they take a shortcut such as 'self-defeanting', in the name of religion which is considered as an atmosphere of a very vulnerable and depressed soul. The radicalism claims that Muslims are not benefited by global civilization which causes resistance to the dominating forces.

The religious radicalism movement, carried out by adherents of Islam fundamentalism, is a defensive reaction against to the fear of traditional lifestyles decreasing in a violent way. In a psychological, it is seen as strength from spiritual sources that move a potential force that can support it. Psychologically, the religion provides the most convincing

\footnotetext{
16Samuel P. Huntington, Benturan Antar Peradaban Dan Masa Depan Politik Dunia (Yogyakarta: Penerbit Qalam, 1996), 76.

${ }^{17}$ Samuel P. Huntington, Benturan Antar Peradaban Dan Masa Depan Politik Dunia.
} 
justification that can be used to against forces that are considered as a threat.

Also, Huntington states that religious communities are communities that have the largest domain where local groups involved in the conflict will provide their support. If a conflict occurs between two groups, then the group rapidly identifies itself as Islam or as Christianity such as the war between Serbian and Croatian in Yugoslav former region and the war between Armenia and Azerbaijan in Caucasus. ${ }^{18}$

This is because the groups who identify themselves as Islam will receive financial and weaponry support from Islam countries in the world, and the groups who identify themselves as Christians will receive financial support from the West. It also proved that the existing the radicalism movement utilizes religion as a justification shield in achieving its goals.

By bringing language and religious symbols and slogans of the radicalism, they attempt to engage religious emotions and gather strength in order to achieve 'noble' goals of their politics. Indeed, it cannot be called as religion manipulating because their behavior partially is based on religious interpretation which used in perceiving historical phenomena.

Adherents of the radicalism want Islam community in Islam countries to maintain pure values of Islam. They consider Western values as a dangerous threat that clashes traditional values of Islam. Logically, violence or the radicalism movement is a method to protect Islam values.

Then, in America Fighting Terrorists, Not Islam book, we can see the clash between western arrogance and Islam intolerance. Hilaly Basya and David Alka claim that the religious violence in a radicalism movement is influenced simultaneously by the social structures pressure that press them in their daily lives due to unfair, dishonest treatment, also motivation and interests the person concerned. ${ }^{19}$ In the midst of daily life, the adherents of the religious radicalism are frustrated due to their

18Ibid.

${ }^{19}$ Hilaly Basya dan David Alka, Amerika Perangi Teroris Bukan Islam (Jakarta: Center For Moderate Moslem (CMM), 2004), 76. 
inability to express emotions intelligently, so they turn it into violence against the main target in order to achieve their desired goal.

\section{Politically Unfavorable Power}

Islam politics contestation in Indonesian political will never subside. On the other hands, the religion seems only regulate the human life spirituality with the Lord without regulating social, political and state life in Indonesia. In the future, the dynamics of relationship between religion and state will always exist in Indonesian politics. Many things can explain this problem, start from sociological, historical, ideological, and political factors.

In Indonesia, Islam political discourse always attracts the attention of many circles. This is because Islam is a religion that is embraced by the majority of the Indonesian. Also, Islam is one of the decisive political forces in the national politics. Therefore, the relationship between Islam and politics always shows an important record, especially in the history of Indonesian politics. The debate about national principle of state before and after the independence is an important record of the history of Islam politics. When a number of articles of UUD 1945 were amended in following new era of Indonesian politics, the old historical issue that underlined the political ideals of Islam also emerged. In fact, the political parties that were born after the end of the new era are still bound strongly.

Islam is one of the political forces in Indonesia politics. Pancasila as raison d'etré is a state basic in Indonesian constitution. On the other hand, diversity, religion, customs, ethnicity, and language are riches and gifts that can be united under Pancasila which were founded by previous 'founding father'. However, there is a tendency that Islam politics contestation still conceals an intention to change it into an Islam ideology. ${ }^{20}$

The fall of Soeharto was a momentum in establishing associations for Islam politics groups. In the first six months of the politics transition,

${ }^{20}$ Bahtiar Effendy, Islam Dan Negara, Transformasi Gagasan Dan Praktik Politik Islam Di Indonesia (Jakarta: Yayasan Abad Democrasi, n.d.), 402. 
no less than 200 mass organizations and political parties were established. They represent various groups such as conservative and puritan, moderate, liberal and secular. Also, the mass organizations based on religious activism are established. ${ }^{21}$

The Islam politics can be defined as a movement that makes religion as their basis struggle. According to some experts, the term of Islam politics can be defined as Islamism; the movement that makes Islam as their basic struggle and it regulates entire their social life including the state.

This term also refers to activities or organizations that move the signs and symbols of Islam tradition because initially Islam has been considered a political religion. Basically, some people believe that the Islam cannot separate religion and politics. It is also used to refer to politics activism involving informal groups that recreate 'repertoires' and frames of Islam traditions reference..$^{22}$

Politics openness and the shifting of authoritarian regimes into democratic regimes seemed to be an essential thing in strengthening the aggregation of Islam politics contestation in the public domain. "Public space" is a space where anyone regardless of religion, ethnicity, race or class can contest freely and fairly. It is similarity and equality of the relation pattern of each party involved in the contestation.

Thus, in a politics context, public space can be defined as a space for citizens; individuals not as members of race, religion or ethnicity, but as politics members (demos). According to Habermas, the public space is not an institution or organization, but it as a very complex network for communicating ideas, opinions and aspirations. Each community, in which public norms are discussed, automatically will produce public space. Therefore, in a democratic country, there is a lot of public space.

In this context, the meaning of public space can be blurred, full of competition and anarchic, even though it is meaningless without rules. 2011), 230.

${ }^{21}$ Luthfi Assyaukanie, Ideologi Islam Dan Utopia (Jakarta: Freedom Institute,

${ }^{22}$ Quintan Wiktorowicz (ed), Aktivisme Islam Dan Teori Gerakan Sosial, Edisi Digital (Jakarta: Yayasan Abad Demokrasi), p. 37. 
Thus, the term "public" itself requires the disaggregation of rational themes and reasons in society. Since the abolition of the single principle of Pancasila, the contestation of Islam politics has increasingly emphasized their existence both through formal mechanisms by establishing Islam-based political parties and non-formal movement groups by establishing Islam mass organizations. ${ }^{23}$

By establishing Islam political parties, the post-reform politics Islam contestation moves in the form of a formal-legal mechanism. Meanwhile, their movement is out of the mainstream framework of the political process, as well as the discourse within the dominant Islam movement. The groups that have interests as contestants, in the contestation of politics public spaces such as Hizbut Tahrir Indonesia, Majelis Mujahidin Indonesia, Front Pembela Islam, Lasykar Jihad and Salafi are representations of a new generation of Islam movements in Indonesia. These new organizations have an ideology basis, thought and strategy that is different from the Islam movement organizations that existed before. They are suspected of puritanism, militant, scripturalist, conservative and exclusive. ${ }^{24}$

The Islam politics contestation has the most extensive (international) network among new movements that are keen to fight for the establishment of Islam law and Islam caliphate. The contestation of the Islam politics movement has a mass base on each group, but

\footnotetext{
${ }^{23}$ Badrus Syamsa Fata (ed), Agama Dan Kontestasi Ruang Publik, (Jakarta: The Wahid Institute, 2011), p. 5.

${ }^{24}$ Among the Islamic movements that deserve to be grouped are militant Islam such as Al-Ikhwan Al-muslimun in Egypt, GIA and FIS in Al-geria, Jema'at Al-Islam in Pakistan, the Palestine Liberation Front, Hizb at-Tahrir and others. Meanwhile in Indonesia there are also religious movements that fall into the militant category, namely the Islamic Defenders Front (FPI), the Indonesian Mujahidin Council (MMI), the Ahlus Sunnah waljamaah Communication Forum (FKAWJ), then the FKWAJ was dissolved by its commander, Ustadz Ja'far Umar Thalib. During the Orla era, there was DI/TII led by Kartosuwiryo who wanted to establish an Islamic State of Indonesia. Likewise Darul Arqam, Abim, the Islamic Republic group, PAS in Malaysia which has the style of an Islamic political party that struggles to enforce Islam into the lives of Malaysian people who are supported by conservative ulama'. See Khamami Zada dan Arif R. Arafah, Diskursus Politik Islam (Jakarta : LSIP, 2004), h. 123.
} 
nowadays in spreading its ideas, they use Islam da'wah movement amar ma'ruf nahi munkar, as what Muhammadiyah and NU did. ${ }^{25}$

\section{Religious Radicalism and Power Politics}

\section{Controlling mosque}

In Sumatera, the group of radical Islam movements uses mosque as an arena of struggle, spread propaganda and the ideology of the Islam movements of each group. In the point view of Islamic movement groups, mosque mastery is a symbol of strengthening the existence of a movement.

The controlling mosque by each group of Islam movements has become common in attracting mass mobilization and sympathizers. Based on researcher observations in Padang, Medan and Riau, almost all mosques in the three research locations have been controlled by Islam movement groups that exist today, such as FPI, MMI, JT, FUI, even in Medan (North Sumatra) there are several mosques that are used as the basis of the Shiite movement, such as the Annur Mosque, the Nurul Ikhlas mosque and the Nurul Yaqin.

The strategies that are used by fundamentalist groups are; first, controlling congregation; excessive imaging in order to convince the congregation that they are Muslims who are taught by the Prophet and his companions and not affected by various changes and progress. Second, seizing mosque management and changing it into mosque activities. Third, preaching related to various problems that are happening, for example Palestine, Syria, Rohingya and so on. Islam oppression in various parts of the world can increase Muslims enthusiasm. The process of controlling mosque can be seen in the scheme below:

${ }^{25}$ M. Imdadun Rakhmat, Arus Baru Islam Radikal: Transmisi Revivalisme Islam Timur Tengah Ke Indonesia, (Jakarta: Erlangga, 2007), p. 17. 


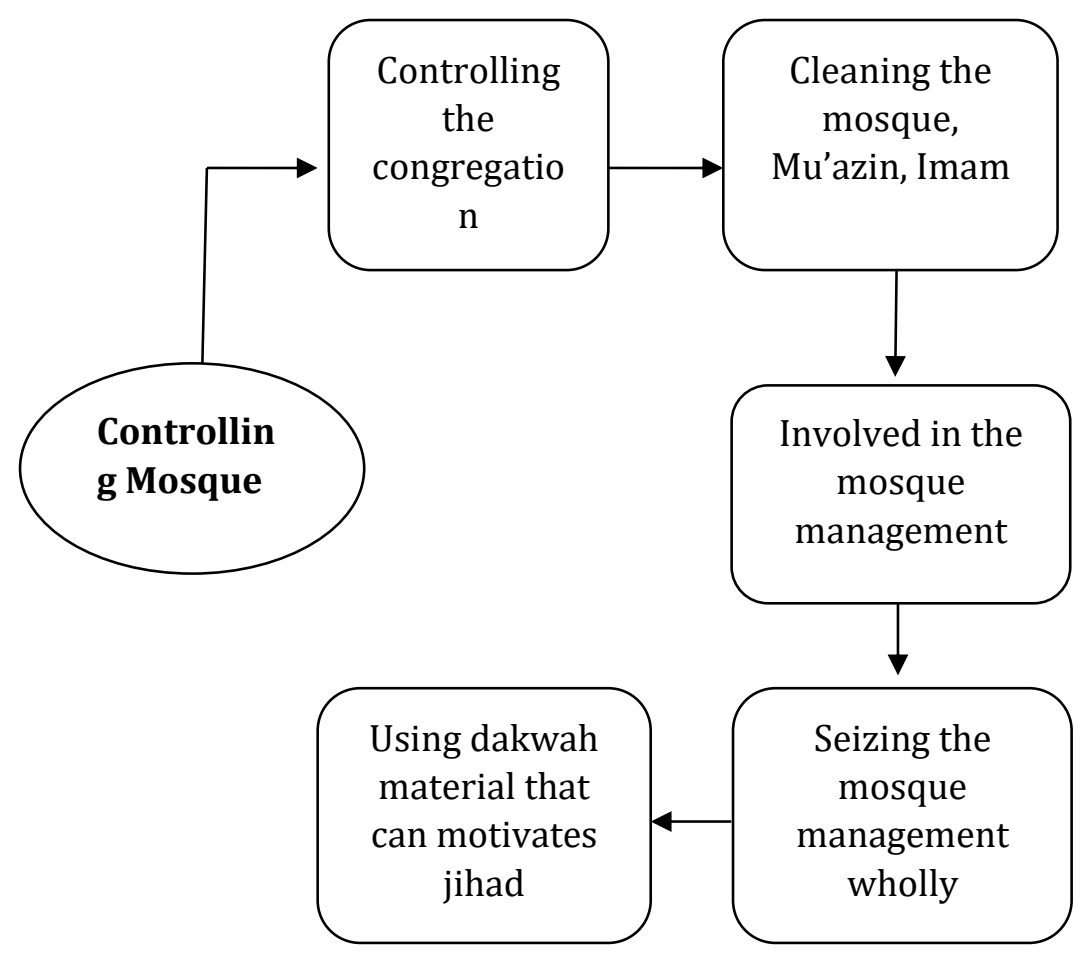

\section{Educational Institution}

The second form of political power of religious fundamentalism is to dominate educational institution. It is a place to gain knowledge for students, and it has been infiltrated by religious fundamentalism movement groups, starting from junior high school to university level.

Furthermore, it can be seen from many students who are involved in terrorism. For example, in a case in Riau, Detachment 88 arrested a student of the University of Riau (UNRI) because he allegedly involved in terrorism, and a homemade bomb as an evident was found in his boarding house.

As reported by BIN, there are many educational institutions in Indonesia that have been influenced by radical ideas. By infiltrating the educational institutions, religious fundamentalism groups recruit members, and they reinforce their existence in the politics power.

Politics power of radical Islam groups in educational institutions is in the form of controlling educational institutions and using their radical ideology. Educational institutions in Sumatera have been dominated 
unconsciously by radical groups, started from early childhood education to university level.

The controlling of educational institutions is a new strategy of radical group movements in order to spread their radical ideology. They offer Tahfiz program which is infiltrated by jihad understanding, the Khilafah and so on.

In fact, the actions of radical groups in controlling educational institutions are largely unknown to the general public, these actions are only known when the society has involved to the educational institutions and follows the activities of radical groups. ${ }^{26}$

Then, by teaching and developing their radical ideology to students, they develop a network of radical groups in Sumatera, and used it as a powerful strategy. After educational institutions were controlled by radical groups in Sumatera, they began to develop organizations by forming organizations in educational institutions.

This act also shows that the existence of radical groups in educational institutions seems to be a political power for radical group existence in Sumatera.

\section{Religious Issues}

The last form of power politics of religious fundamentalism is by manipulating religious issues. For example, a case of religion defamation, Khilafah State, amar ma'ruf nahyi mungkar, and so on. Manipulating religious issue is quite effective as one of the strategies of religious fundamentalist groups in order to maintain their existence in the society.

A clear example of manipulation of religious issue was to subvert Ahok (the governor of DKI) who want to be elected again as the governor of DKI Jakarta at that time. It was powerful enough to lead Anis Baswedan to become governor and defeated Ahok. These religious issues are still used by religious fundamentalists as their politics power. These also can be used to unite people when regional election in Sumatera.

26Interview with Muhammad Gazali, ex-terrorist in Medan on August 14, 2018. 
In Indonesian, Islam fundamentalism groups are represented by Islam movements such as FPI, PUI, Laskar Jihad, and etc. The Islam movement offers Islam law as problem solving of nationalism. They agree that the disappearance of Islam faith and Islam law in society makes Indonesian nation collapsed, especially Indonesian Muslims as the majority groups in this country. ${ }^{27}$

For fundamentalist Islam, Al-Qu'an and as-Sunnah are the way of life that cannot be separated. They understand religious texts (nash) very textually and rigidly. In this case, Islam observers define them as scripturalist. Their understanding about Islam cannot be separated from the understanding of the previous Ulama (Salaf) such as Ibn Taymiyah, Ibn Qayim al-Jauziyah, Muhammad bin Abdul Wahab, Ahmad bin Hanbal and all the figures of the Salaf Ulama who are grouped as Ahlul Hadith.

Each value of religion is considered sacred by adherents and they are always actualized it in daily life. Then, they internally use religion as a normative reference in daily behavior, both individuals and groups. While externally, the diversity of educational backgrounds and sociocultural conditions, bringing the placement of religion as a normative reference that cause diversity, both at the level of perception, interpretation and at the level of expression of diversity itself.

Human behavior changing is influenced by many factors, both internal and external factors. Relating to internal factors, human behavior is influenced, among others, by the norms and values that are embraced or believed by someone. ${ }^{28}$ Even the formation of human groups is influenced by the similarity of norms and values and it distinguishes their characteristics from the other groups. ${ }^{29}$

\section{Religious Radicalism as a Threat}

\section{The Dangers and Threats to the Country}

The terrorism threat to the country is a real threat. As stated by Francis Fukuyama in his book "The End of History", a new era after the

\footnotetext{
${ }^{27}$ Budi Winarno, Isu-Isu Global Kontemporer, (Jakarta: CAPS, 2011), p. 90.

${ }^{28}$ Mehdi Muzaffari, Kekuasaan Dalam Islam, Terj. Abdurrahman Ahmed (Jakarta: Pustaka Panjimas, 1994), 34.

${ }^{29}$ Mehdi Muzaffari, Kekuasaan Dalam Islam, Terj. Abdurrahman Ahmed.
} 
Cold War. In a new era of world, democracy and economic liberalization will be the basic values. A new era that will make the world more peaceful and more prosperous due to the capitalism, when the United States as the only superpower country, both in the politic and economic, there is no a barrier in spreading democracy and liberalization. United State obsesses to turn all countries in the world into democracies, because 'fellow democracies don't fight each other'. ${ }^{30}$

Francis Fukuyama also describes that the post-Cold War situation as the final era of history, the final point of the human ideology evolution and the increasingly universal liberal democracy as the final form of human government. Here, Fukuyama also speculates that the end of history will make war useless because democracy can prevent countries from fighting each other. However, it is not yet possible or at least still requires time and process to make it happen, when the polarization of ideological poles in the world ended in victory on the United State side, when the hegemony of American power began to spread to other parts of the world, and then there will also be conflicts and new scenarios.

The track record of radical group violence in Indonesia need more attention, especially desire to develop mass murderer weapons technology, including the use of mass media to convey and spread the idea of fundamentalism in fostering radicalism in the society, it is also a necessity to consider terrorism as a Transnational crime. ${ }^{31}$

In Sumatera, it is found that fundamentalism brought several dangers and threats to the country. First, it always influences government policy and religion relationship. Second, there has been discrimination between minority and majority religion. Third, it threats security, always sweeps and expulses of groups deemed to violate the provisions of Islam law. Fourth, it provoked the society, especially in dakwah. Fifth, the country uses discrimination policies toward fundamentalism. The danger and threat of fundamentalism to the country can be seen in the scheme below:

${ }^{30}$ Francis Fukuyama, The End of History (Terj) (Yogyakarta: Qalam, 2005), 53.

${ }^{31}$ Muhammad Mustofa, Krimininologi, Kajian Sosiologi Terhadap Kriminalitas, Perilaku Menyimpang Dan Pelanggaran Hukum (Jakarta: FISIP UI Press, 2007), 40. 


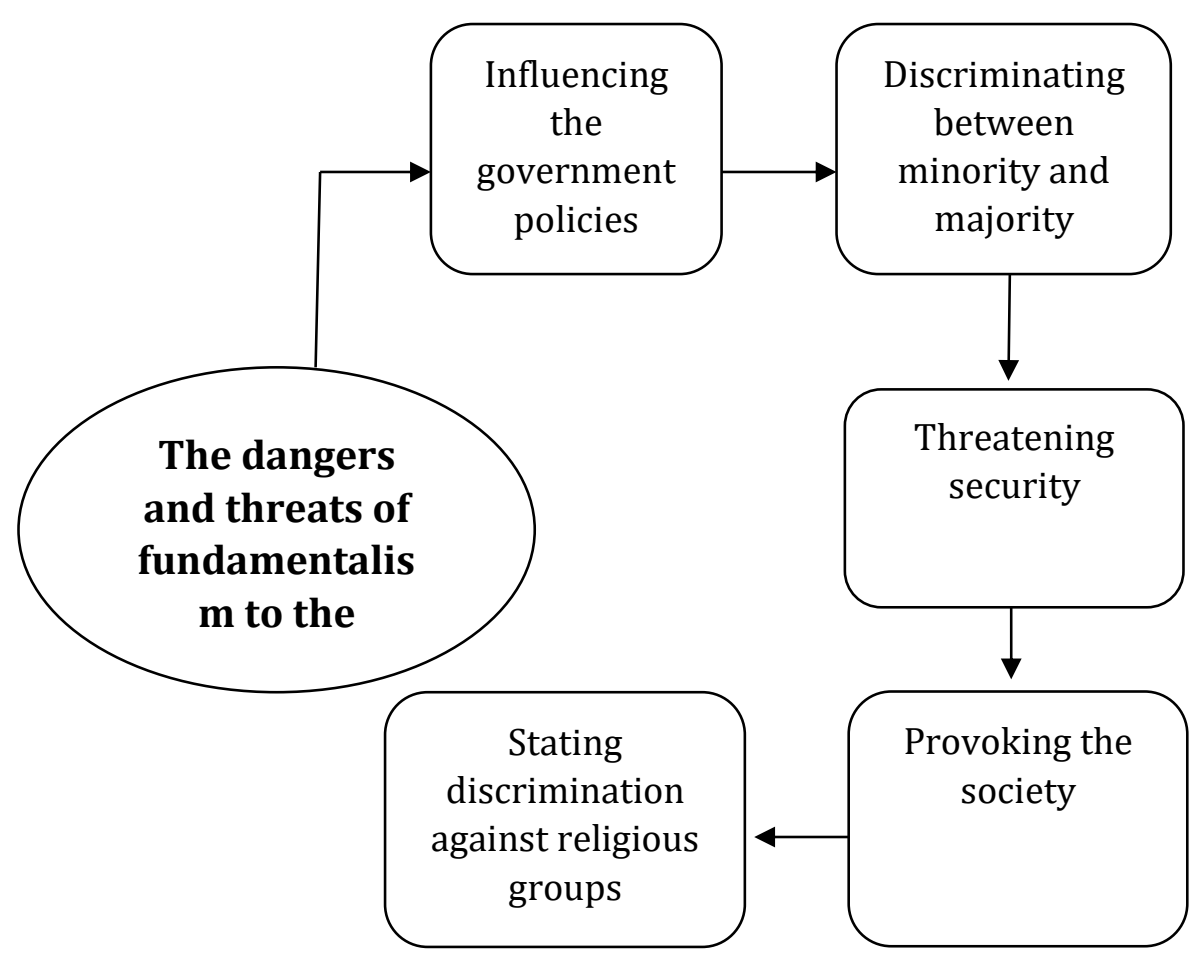

\section{The Dangers and Threats to the Religion}

Religion should not cause violence. However, it can cause violence if it is related to other factors, such as group interests or political oppression. It also can be misused and misdirected from both external and internal sides. Externally, prophetic religions, such as Islam and Christianity, tend to do violence when their identity is threatened. Meanwhile, internally prophetic religions tend to do violence because they believe their actions are based on God's will. Therefore, understanding religion or how religion is interpreted is one of the reasons underlying religion-politic violence.

Religion-politics that occur in many new independent countries, which struggle to determine their national identity and the existence of minority groups that emphasize their rights make religion plays important role, such as in Lithuania, Armenia and Azerbaijan. The authorities consider violence, terror and authority as prerogative right that cannot be separated from power. Religion has been manipulated for politic purposes to liberate itself from moral obligations if its existence is 
threatened. Violence has been framed by "religion" as an expression of the desire to neutralize sin.

The country uses violence to maintain power. The outbreak of violence during the new era with the emergence of radical Islam groups, the Tanjung Priok massacre, and the destruction of worship place are the ways of government to marginalize Islam groups and to maintain power. Thus, the emergence of radical Islam groups is caused more by the interests of certain groups by using religion as a tool of legitimacy. ${ }^{32}$

Moreover, violence is often identified as terrorism. It is used generally in political terms as an attack on the civil during the Terror regime in the French revolution of the late XVIII century. In this case, the public claims that the violence is caused by terrorism.

In Sumatra, it is found that fundamentalism brought several dangers and threats to the religion; first, religion is used as a justification tool for acts of violence. By using religious symbols and verses of AlQur'an, they legalize their attitudes and behavior in dakwah. Second, religion does not bring peace, tranquility and so on. The radical behavior of fundamental group gives a signal to the general public that Islam does not bring peace and tranquility. Third, religion truth does not apply universally. Islam as a religion that rahmatan lil'alamin is only a concept. Fourth, often internal conflict of religious communities because their behavior is different, often gets resistance from other Islam communities. The dangers and threats of fundamentalism to the religion can be seen in the following scheme:

${ }^{32}$ Muhammad Mustofa, Krimininologi, Kajian Sosiologi Terhadap Kriminalitas, Perilaku Menyimpang Dan Pelanggaran Hukum. 


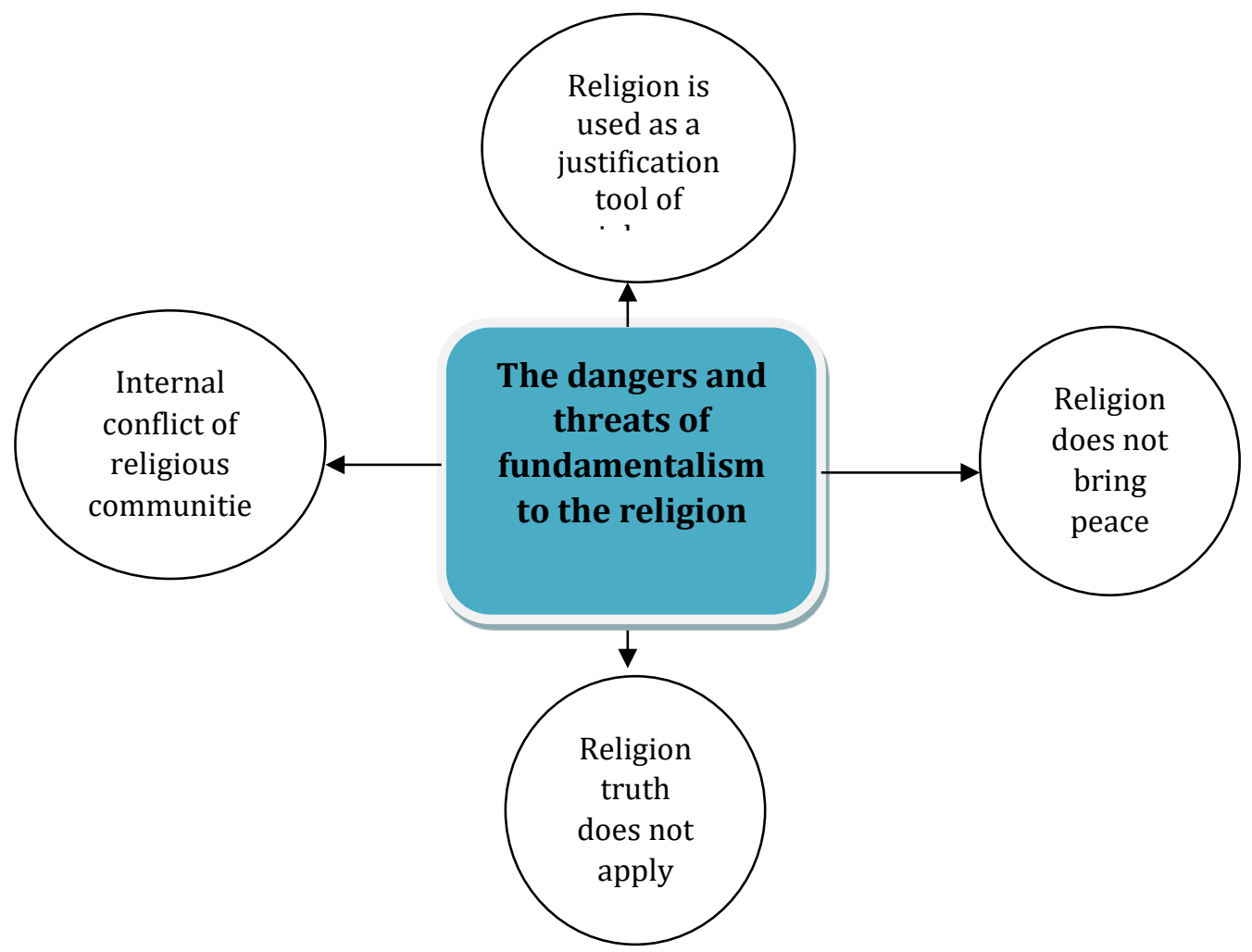

\section{Metamorphosis of Fundamentalism into Radicalism and Terror}

The radicalism is the cause of terrorism emergence. It is an attitude that wants total change, and it is revolutionary by overturning existing values drastically through violence and extreme actions. There are several characteristics that can be categorized as a radical attitude; 1) intolerant (disrespect the opinions and beliefs of others), 2) fanatic (always feel right), 3) exclusive (distinguish themselves from Muslims generally) and 4) revolutionary (tend to use methods violence in achieving goals. ${ }^{33}$

Having radical attitudes does not make a person be a terrorist. There are other factors that motivate someone to join the terrorism network. The motivation is caused by several factors. First, domestic factors, such as poverty, injustice or feeling disappointed with the

${ }^{33}$ Interview with Muhammad Gazali, ex-terrorist in Medan on November 162018 , at $16.00 \mathrm{WIB}$. 
government. Second, international factors, the influence of the foreign environment that provides the driving force for the growth of religious sentiment such as global injustice, arrogant foreign policy, and modern imperialism of the superpower countries. ${ }^{34} \mathrm{Third}$, cultural factors, which are closely related to narrow religious understanding. Radical attitudes are motivated by various factors above often make a person choose to join terrorism networks. ${ }^{35}$

Furthermore, it is found that many radical groups turn into terrorists due to cultural, educational and environmental factors where these radical groups live. For example, radical groups in Sumatera commit acts of terror because of injustice of the country towards Muslims. Besides, this is because of invitations from other radical groups.

Radical actions that turn into jihad actions are mostly caused by doctrine factors (brainwashing). Then, they use the bride and groom (suicide bombing) as a new understanding of jihad. For example, they emphasized that jihad is fardhu 'ain or the individual obligations of every Muslim which must be carried out whenever and wherever. ${ }^{36}$

Moreover, they were also taught that jihad is the highest deed of worship in Islam. They also gained an understanding that the meaning of jihad was qital fisabilillah. It means that jihad was considered as the highest deed of worship in Islam. This new understanding slowly changed the orientation from radical groups to jihad groups. They also changed the orientation of their actions from the anti-immoral movement to the jihad movement. They were against people or groups that they considered as infidels.

In May 2018, Laskar Hisbah declared jihad or war against the police. The declaration was made at a meeting in the Nurul Iman Mosque which was the headquarters of this group. In the midnight meeting, Rusdiayanto gathered around 50 members of Hisbah. Then, he gave

\footnotetext{
${ }^{34}$ Interview with Prof. Dr. Syahrin Harahap, Chairman of the North Sumatra BNPT, on November 16, 2018 in Medan.

${ }^{35}$ Harvey W. Kushner, 'Encyclopedia of Terrorism', Sage Publication, (London, 2003), p. xxiii.

${ }^{36}$ Adapted from the results of FGDs in three research locations, (West Sumatra, North Sumatra and Riau).
} 
tausiah about the importance of fighting against the police who were considered as ansharut thogut or Indonesian government soldiers who were considered as infidels. After the tausiah program, participants were divided into three groups and each group performed dead pledges.

Since 2010, jihadi groups have considered the police as their main enemy. It started from Aceh terrorism case in early 2010 which led to the arrest of more than one hundred jihadist activists and the killing of jihadist leaders such as Dulmatin, Maulana and others that angered many jihadists. The climax was in August 2010 when Abu Bakar Basyir was arrested by the police because he was accused in involving terrorism in Aceh. Among jihadis, Ba'asyir was a highly respected figure, and as a result it angered many people. ${ }^{37}$

This anger was also legitimized by various writings circulating among jihadis, it ordered to attack the police. For example the article untitled "O Angel of Heaven ... Tell You with the Head of Detachment." In this article, it is clearly stated that if a Muslim is killed, then it is obligatory for other Muslims to commit Bai'at because it was done by the companions of the Prophet who carried out the oath of allegiance when he heard rumors that Usman bin Afan was killed by Islam enemy.

\section{Counteracting Religious Fundamentalism}

\section{The Efforts to De-radicalize the Country}

As the findings of this study show, that intolerance is the starting point of terrorism, so de-radicalization work is not enough to only be directed towards those who become terrorists but also against radical organizations, intolerant groups, including the community do not to follow radical ideology and transformation become a terrorist. Therefore, the de-radicalization program must be focused on three groups.

First is the general public, especially Muslims. De-radicalization in this context aims to protect the public from following exclusive and puritan religious ideology and from engaging in radical and intolerant 
actions. Based on BNPT, this kind of activity is categorized as counterradicalization.

De-radicalization in the form of prevention can be done by strengthening a number of national discourses in the general public, especially Islam perspective. The public should understand that the existing national discourse does not contrast to the religion. Islam is an inclusive religion, open to values, cultures and civilizations, but it should not contrast to Islam ideology. In the point of view of Islam, maintaining the existence of Islam does not mean restrict interaction to other civilizations because Islam civilization is a dynamic and active civilization, not exclusive and not introvert to other cultures and civilizations.

Second is the radical group. In this context, de-radicalization is intended to eliminate a number of radical ideologies by using a counter narrative approach, so they are free from the radical ideology. At least, they do not join a terrorist group. One of the radical ideologies that must be avoided is jihad doctrine which is misunderstood by terrorists. Jihad is defined as the highest gift from God to all of His servants who died in spreading noble teaching of the religion.

Furthermore, the jihad doctrine is often used as a justification by radical group actions. Jihad is a mental and ethical coaching for a person to fight in any conditions. In linguistic terms, it means to seriously use all energy and material, such as assets, or non-material things such as enthusiasm, soul, and etc.

In an Arabic dictionary, Lisanul Arabic, it is mentioned that the word jihad comes from the word of al-jahdu or al-juhdu which means ability. Jihad means using all abilities. Relating to the meaning above, jihad becomes the most basic Islam teaching, because it encourage Muslims to always carry out the religion teachings totally, wholeheartedly, and sincerely because of God.

In a book titled Tasliythul Adhwa 'Ala ma Waqa'a fi Al-Jihad min Akhta' (Revealing Mistakes in Understanding Jihad), Sheikh Hamdi Abdurrahman Abdul Azim, Najih Ibrahim Abdullah and Ali Muhammad Ali Syarif convey that jihad is not a purpose because the main purpose of the Islam is to uphold the teachings of God and bring human to His path. 
Next is the ideology of Islam country that is believed by radical groups. The Islam country is the highest and final purposes of terrorists. Actually, the ideology problem of the Islam country and Pancasila has surfaced in the early days of independence, but the problem has never been completely resolved until this day. The ideology of the Islam country continually exist behind the tendency of salafism among religious adherents, a tendency to imagine the past fully sacred, ideal, and perfect.

\section{Role of Religious Leaders}

Jihad as qital can be defined as a war against the Islam enemies. It can provide a strong encouragement for violence in the name of religion. In other words, if Muslims are attacked, wronged, and treated unfairly, they defend the Muslim community by jihad. They regard that nonMuslims are always hostile to Islam in non-Muslim majority areas. The perception provides great potential for them to accuse non-Muslims as enemies who threaten the existence of Muslims, so Muslims must be prepared to do jihad against them.

In social, political and religious relations, Islam has provided rules, especially in relation to non-Muslims. Relating to the issue of radicalism and terrorism, religious leaders must work together. All aspects must be involved in eliminating religious radicalism and terrorism. Returning the real meaning of Islam is a big responsibility of the religious leaders. However, the issue of religious radicalism and terrorism will never disappear as long as the religious leaders do not take part in this issue.

The religious leaders have to increase society awareness related to the religion understanding, rahmatan lil'alamin, Islam is humanist and anti-violence religion. In addition, they can create friendship forum between religions in order to spread understanding to the radical groups that we are God's creature.

\section{De-radicalization of Educational Institutions}

Curriculum development in educational institutions must be preceded by socialization so that the developer (teacher) can develop the curriculum in the form of learning plans / unit lessons, and manage the learning process in class and evaluation in accordance with the multicultural principles of the curriculum. Important thing that should be 
consider in developing a multicultural curriculum is the lack of uniformity. The curriculum must clearly state that students are not learning for the subjects, but the subjects are a medium for developing student personalities. In developing this personality, the curriculum approach requires a curriculum that is able to be a medium for national cultural development.

The curriculum development related to the development of various curriculum components such as objectives, content, learning experience, and evaluation. The objectives are that the students are able to learn based on the curriculum. The quality sources are not only limited to the quality determined by the discipline of science but the human qualities expected is creativity, discipline, hard work, ability to work together, tolerance, critical thinking and so on. They must be highlighted as the curriculum goals. The multicultural curriculum must be able to emphasize the education purposes which are equal or more important than the teaching purposes.

The society as a source of learning must be utilized as a source of curriculum content. Therefore, values, morals, habits, customs/traditions, and cultural traits must be accommodated as curriculum content. Curriculum content is society and culturally based and opens to problems of the society. It has to make the students feel that the school is a social institution that can develop the human quality of the students, including curriculum content that can support the development of the student's humanity is religion, literature, language, sports and art.

Curriculum development as a document places students as subjects in learning, so students who learn and interact with learning sources (including the society) and teachers act as facilitators. In multicultural education, the approach of students as subjects in learning means that the method is a teacher's tool in helping students learn, it is determined how the way students learn.

Curriculum development as a process is determined by the teacher both in the context of centralization and the context of autonomy. The teacher's role is a curriculum developer that is directly related to students, therefore if the curriculum development is not appropriate to 
the curriculum as an idea and as a document, the curriculum as a process is not advanced.

Knowledge, understanding attitudes, and teacher's willingness to the multicultural curriculum are crucial aspects in the curriculum as a process. There are four things that should be considered by teachers in developing curriculum as a process; (a) the position of students as subjects in learning; (b) the way students learn is determined by their cultural background; (c) the cultural environment of the majority of students' societies and the cultural behavior entry; (d) students' cultural environment as a learning source. ${ }^{38}$

\section{Conclusion}

Understanding the activities of radicalism can be categorized as terrorism where there is a threat and violence. Therefore, Indonesian must fight together to minimize the impact of radicalism and to encourage the government to find out why the radicalism emergence by trying to limit the potential development of the radical ideology from the outside, such as fortifying Indonesia from unjustified ideas by religion. One strategy is by reinforcing the ideology and values of Pancasila and religious understanding in accordance to Islam teachings through dakwah, family education, discussions, etc.

Promoting anti-radical propaganda should be one of the main agendas to combat radical movements in the campus area. It becomes increasingly important because the organization has many networks and followers so that it will facilitate propaganda to its cadres. If it is done consistently, then slowly but surely the radicalism movement can be prevented without having to use repressive act that will take a lot of victims and costs.

Strategic, innovative, integrated, systematic, serious and comprehensive steps are needed. Also, we should pay attention to the network, modus operation, and raison d'etre of this movement. It is necessary to combine ideological steps, de-radicalization programs through civil society, and economic and social approaches. It is to prevent former activists from radical and terrorist movements returning to their

\footnotetext{
${ }^{38}$ S. Hamid Hasan, "Pendekatan Multikultural Untuk Penyempurnaan Kurikulum Nasional", Kompas, 2003.
} 
old communities. The "humanizing" program is also one of the prerequisites in preventing the spread of radicalism and terrorism.

Therefore, the government must take responsible for the security of its society. The firmness and seriousness of the government in protecting its citizens in creating a sense of security and preventing violence become an urgent constitutional mandate.

In order to avoid radicalism in the name of religious organizations, there are essential things that can be done such as not easily believing in any religious organization, asking about the identity of the religious organization, understanding that religious organizations must be open, and avoiding organizations that do strange thing by offering money, changing our name, or cutting off ties with family.

\section{Bibliography}

Ahmad Norma Permata. Agama Dan Terorisme. Surakarta: Muhamadiyah University Press, 2006.

Badrus Syamsa Fata (ed). Agama Dan Kontestasi Ruang Publik. Jakarta: The Wahid Institute, 2011.

Bahtiar Effendy. Islam Dan Negara, Transformasi Gagasan Dan Praktik Politik Islam Di Indonesia. Jakarta: Yayasan Abad Democrasi, n.d.

Beverley Milton-Edwards. Islam and Violence in the Modern Era,. New York: Palgrave Macmillan, 2006.

Francis Fukuyama. The End of History (Terj). Yogyakarta: Qalam, 2005.

Habibi, Mulkan. "Framing Kompas. Com Dan Republika. Co. Id Atas Pernyataan Ahok Tentang Dibohongi Al-Maidah 51." KAIS Kajian Ilmu Sosial 30, no. 1 (2021): 67-84.

Hilaly Basya dan David Alka. Amerika Perangi Teroris Bukan Islam. Jakarta: Center For Moderate Moslem (CMM), 2004.

Irawan, Deni, and Zarul Arifin. "The Relationship Between Islamic Fundamentalism and Radicalism With Social Conflict." Al-Tahrir 21, no. 1 (2021): 35-53.

Kushner, Harvey W. “Encyclopedia of Terrorism.” Sage Publication. 2003.

Kwon, Heonik, and Seong Nae Kim. "Religions in Cold War Korea and Peacemaking: Guest Editors' Introduction." Journal of Korean Religions 9, no. 1 (2018): 5-10. 
Luthfi Assyaukanie. Ideologi Islam Dan Utopia. Jakarta: Freedom Institute, 2011.

M. Imdadun Rakhmat. Arus Baru Islam Radikal: Transmisi Revivalisme Islam Timur Tengah Ke Indonesia. Jakarta: Erlangga, 2007.

Mahfud, C., N. Prasetyawati, W. Wahyuddin, Z. Muhibbin, D. S. Y. Agustin, and H. Sukmawati. "Religious Radicalism, Global Terrorism and Islamic Challenges in Contemporary Indonesia." Jurnal Sosial Humaniora 11, no. 1 (2018): 8-18.

Mandaville, Peter. Islam and Politics. Routledge, 2020.

Mehdi Muzaffari. Kekuasaan Dalam Islam, Terj. Abdurrahman Ahmed. Jakarta: Pustaka Panjimas, 1994.

Mietzner, Marcus, and Burhanuddin Muhtadi. "Explaining the 2016 Islamist Mobilisation in Indonesia: Religious Intolerance, Militant Groups and the Politics of Accommodation." Asian Studies Review 42, no. 3 (2018): 479-97.

Muhammad Mustofa. Krimininologi, Kajian Sosiologi Terhadap Kriminalitas, Perilaku Menyimpang Dan Pelanggaran Hukum. Jakarta: FISIP UI Press, 2007.

Quintan Wiktorowicz (ed).Aktivisme Islam Dan Teori Gerakan Sosial. Edisi Digi. Jakarta: Yayasan Abad Demokrasi, n.d.

S. Hamid Hasan. "Pendekatan Multikultural Untuk Penyempurnaan Kurikulum Nasional."' Kompas, 2003.

Sahrasad, Herdi, and Al Chaidar. "Radicalism, Fundamentalism and Terrorism in Indonesia: A Political Reflection." Journal of Asia Pacific Studies 5, no. 2 (2019).

Samuel P. Huntington. Benturan Antar Peradaban Dan Masa Depan Politik Dunia. Yogyakarta: Penerbit Qalam, 1996. 